\title{
LONG-DISTANCE MOVEMENT IN A DUSKY GREAT HORNED OWL AND LIMITS TO PHYLOGEOGRAPHY FOR ESTABLISHING PROVENANCE
}

\author{
Robert W. Dickerman ${ }^{1}$, Sabrina M. McNew ${ }^{1}$, and Christopher C. Witt ${ }^{1,2}$
}

\begin{abstract}
Aвstract.-The Dusky Great Horned Owl (Bubo virginianus saturatus) of the Pacific Northwest region of North America is generally considered to be nonmigratory. Here we report a specimen of a Dusky Great Horned Owl that was salvaged in New Mexico and identified based on comparison of its plumage with a large series of museum skins. We attempted to corroborate this identification by comparing mitochondrial DNA sequences between the specimen and a representative sample of 5 Great Horned Owl subspecies from western North America. This analysis revealed minimal mitochondrial genetic variation and no evidence of population genetic structure, suggesting that the marked plumage differences among subspecies evolved since the late Pleistocene. To evaluate the possibility that the salvaged specimen was transported after death, we analyzed its stomach contents. The stomach contained remains of a desert cottontail (Sylvilagus audubonii), a locally abundant rabbit species in central New Mexico. The mitochondrial haplotype of the rabbit was novel but closely related to haplotypes found in New Mexico and west Texas. This is the first report of long distance movement in the Pacific Northwest subspecies of Great Horned Owl, though we cannot rule out the possibility of anomalous melanism. Although there is tremendous potential for forensic-style phylogeographic investigation of animal movements, this study illustrates that sequence databases are not yet adequate to the task, even for common North American vertebrate species.
\end{abstract}

Resumen.-Por lo general, se considera que el Búho Americano (Bubo virginianus saturatus) de la región Noroeste del Pacífico de Norteamérica no tiene hábitos migratorios. En este estudio nos referiremos a un espécimen de Búho Americano que se rescató en Nuevo México y se identificó de acuerdo con comparaciones del plumaje con una gran cantidad de pieles. Intentamos corroborar esta identificación comparando secuencias de ADN mitocondrial del espécimen con una muestra representativa de cinco subespecies del Búho Americano del oeste de Norteamérica. Este análisis reveló una variación mitocondrial genética mínima y ninguna evidencia de estructura genética de la población, lo cual indica que las marcadas diferencias del plumaje entre subespecies se han ido desarrollando desde el final del Pleistoceno. Para evaluar la posibilidad de que el espécimen que se rescató haya sido transportado después de su muerte, analizamos el contenido del estómago, en el cual se halló una especie de conejo que abundaba en la zona, en el centro de Nuevo México, llamado conejo del desierto (Sylvilagus audubonii). El haplotipo mitocondrial del conejo era nuevo, pero se relacionaba estrechamente con los haplotipos que se encuentran en Nuevo México y en el oeste de Texas. Este es el primer informe de migración a larga distancia de las subespecies del Búho Americano del noroeste del Pacífico, sin embargo existe la posibilidad de melanismo anómalo. Existen grandes posibilidades de realizar investigaciones filogeográficas de estilo forense sobre la migración de los animales, este estudio demuestra que las bases de datos de las secuencias no son suficientes para realizar esa tarea, inclusive en los casos de especies comunes de vertebrados de Norteamérica.

The Great Horned Owl (Bubo virginianus) is a widespread and geographically variable New World species, with North American populations comprising at least 11 subspecies that differ in plumage, size, habitat, and vocalizations (Houston et al. 1998, Dickerman and Johnson 2008). In New Mexico, B. v. pallescens breeds at low elevations, whereas $B . v$. pinorum breeds in montane forests (Dickerman and Johnson 2008). Salvage efforts over the last $\sim 25$ years have yielded $>300$ specimens from New Mexico, including B. v. pallescens, B. v. pinorum, and many fall migrants or wintering individuals of subspecies from the northern Rockies (B. v. lagophonus), the northwestern Great Plains to the subarctic $(B$. $v$. subarcticus), and the eastern Great Plains (intergrades between B. v. pallescens and B. $v$. virginianus). Latitudinal migration or irruptive winter movement is clearly part of the annual cycle for at least the northernmost subspecies of Great Horned Owl; however, the nature of the owls' movements is poorly known (Houston et al. 1998). The "Dusky" Great Horned Owl (B. v. saturatus) has been thought to be an exception. Its range is restricted to the

\footnotetext{
${ }^{1}$ Museum of Southwestern Biology and Department of Biology, University of New Mexico, Albuquerque, NM

${ }^{2}$ Corresponding author. E-mail: cwitt@unm.edu
} 
rainforests of the Pacific coastal zone of the Northwest from Glacier Bay, Alaska, to approximately Santa Cruz, California (Grinnell and Miller 1944, AOU 1957). Grinnell and Miller (1944) note that B. v. saturatus occurs "in 'diluted' manifestation" at the southern and southeastern borders of its distribution. Bubo $v$. saturatus has long been considered to be essentially sedentary (Houston et al. 1998) or subject to only short-distance movements. For example, the 5th AOU checklist (1957) notes that it is a winter visitant to interior British Columbia. Grinnell and Miller (1944) also cite one specimen (MVZ 59111) from Grizzly Island, Solano Co., California, from 1 November 1941, as a "southward straggler." A search of ORNIS revealed 5 additional, modestly extralimital specimens, identified as $B$. $v$. saturatus, which were collected between October and December from western Montana (MVZ 79183) or San Luis Obispo Co., California (ROM 86844, 86851, 86852; UCLA 7257). However, RWD examined the plumage of the western Montana specimen and determined it to be B. v. lagophonus.

We report the first specimen (MSB:Bird :37574) from New Mexico that is a typical B. $v$. saturatus by plumage. It was delivered dead to the gate of a rehabilitator in Corrales, Bernalillo Co., New Mexico, on 30 October 2011 and was said to be from the adjacent suburb of Rio Rancho. It obviously was not a captive bird, considering the absolute lack of feather abrasion and a small, partly digested desert cottontail (Sylvalagus audubonii) in its stomach.

DNA sequencing has recently facilitated our ability to identify the provenance of migrant (e.g., Kimura et al. 2002, Ruegg and Smith 2002, Webster et al. 2002, Wink 2006) and vagrant birds (e.g., Witt et al. 2010, Baumann et al. 2011, 2013, Engel et al. 2011, Johnson et al. 2011). The basis for this method is that populations that are geographically separated accrue unique genetic characteristics over time by genetic drift or natural selection acting on new or existing alleles. Geographically isolated populations are typically genetically divergent and diagnosable by molecular means, even if they have not diverged at all genetic loci (Avise 2000, Webster et al. 2002). The mitochondrial genome evolves much faster on average than nuclear DNA because of its higher mutation rate and smaller effective population size, and as a result, mitochondrial DNA sequence divergence is often a leading informative indicator of geographic provenance (Zink and Barrowclough 2008). The key limitation for using mitochondrial or other DNA sequences to efficiently infer avian movements or population connectivity is that reference databases must contain variable genetic sequences with known geographic structure.

Here we examine the identification and geographic origin of this anomalous New Mexico Great Horned Owl specimen by comparing its plumage with the extensive series of museum skins at the Museum of Southwestern Biology (MSB), as well as comparing its mitochondrial DNA with 11 other Great Horned Owl specimens representing 5 subspecies. We also attempt to establish the geographic location at which the owl consumed its last meal by analyzing mitochondrial DNA from the rabbit in its stomach.

\section{Methods}

We extracted DNA from muscle tissue of MSB:Bird:37574 and 11 other Great Horned Owl specimens from the MSB Bird Collection using Qiagen DNEasy kits. In addition, we extracted DNA from the small mammal (MSB:Mamm:262536) found in the stomach of MSB:Bird:37574 and from one desert cottontail specimen collected in Rio Rancho, New Mexico, and held in the MSB Mammal Collection (MSB:Mamm:85844; Table 1).

We amplified the mitochondrial NADH dehydrogenase subunit 2 (ND2) gene for each owl specimen by using primers L5219 and H6313 (Sorenson et al. 1999), with reagent concentrations and thermalcycler protocols following Witt et al. (2010). We amplified and sequenced the mitochondrial cytochrome $b$ (cyt $b$ ) gene of the 2 mammals by using primers L14724 and H15915 (Irwin et al. 1991) with the same PCR protocols as for the owls, except for a lower annealing temperature $\left(47^{\circ} \mathrm{C}\right)$. We sequenced with external primers, and with one additional internal primer for cyt $b$ (L15171; Spradling et al. 2001), using BigDye 3.1 chemistry (ABI) and an ABI 3130 sequencer. We assembled and edited sequences manually using Sequencher 4.7 (GeneCodes, Ann Arbor, MI). We used the software package MUSCLE (Edgar 2004) to align ND2 and cyt $b$ sequences and used 
TABLE 1. Museum of Southwestern Biology specimens and Genbank accession numbers for DNA sequences of Great Horned Owls (Bubo virginianus) and cottontail rabbits (Sylvilagus spp.) used in this study.

\begin{tabular}{|c|c|c|c|c|}
\hline $\begin{array}{l}\text { Catalogue no. } \\
\text { or reference }\end{array}$ & Species & Subspecies & Origin & $\begin{array}{l}\text { Genbank } \\
\text { accn. no. }\end{array}$ \\
\hline MSB : Bird : 28856 & Bubo virginianus & saturatus & Oregon & JQ965161 \\
\hline MSB : Bird : 29188 & Bubo virginianus & pinorum & Washington & JQ965162 \\
\hline MSB : Bird : 29190 & Bubo virginianus & lagophonus & Oregon & JQ965163 \\
\hline MSB : Bird : 29189 & Bubo virginianus & pinorum & Washington & JQ965164 \\
\hline MSB : Bird : 37574 & Bubo virginianus & saturatus & New Mexico & JQ965165 \\
\hline MSB : Bird : 25642 & Bubo virginianus & lagophonus & New Mexico & JQ965160 \\
\hline MSB : Bird : 20766 & Bubo virginianus & pallescens & New Mexico & JQ965157 \\
\hline MSB : Bird : 20124 & Bubo virginianus & pallescens & New Mexico & JQ965155 \\
\hline MSB : Bird : 21659 & Bubo virginianus & pinorum & New Mexico & JQ965156 \\
\hline MSB : Bird : 23281 & Bubo virginianus & pinorum & Utah & JQ965158 \\
\hline MSB : Bird : 23738 & Bubo virginianus & pinorum & Texas & JQ965159 \\
\hline MSB : Bird : 18029 & Bubo virginianus & subarcticus & New Mexico & JQ965154 \\
\hline MSB : Mamm : 85844 & Sylvilagus audubonii & & New Mexico & JQ965153 \\
\hline MSB : Mamm : 262536 & Sylvilagus audubonii & & New Mexico & KC661076 \\
\hline Nalls et al. 2012 & Sylvilagus audubonii & & Texas & HQ143463 \\
\hline Ramirez-Silva et al. 2010 & Sylvilagus audubonii & & Mexico & HQ596488 \\
\hline Halanych and Robinson 1999 & Sylvilagus audubonii & & Unknown & U58938 \\
\hline Matthee et al. 2004 & Sylvilagus audubonii & & Unknown & AY292722 \\
\hline Matthee et al. 2004 & Sylvilagus aquaticus & & Unknown & AY292726 \\
\hline Matthee et al. 2004 & Sylvilagus floridanus & & Unknown & AY292724 \\
\hline Matthee et al. 2004 & Sylvilagus nuttallii & & Unknown & AY292723 \\
\hline Matthee et al. 2004 & Sylvilagus obscurus & & Unknown & AY292725 \\
\hline Matthee et al. 2004 & Sylvilagus palustris & & Unknown & AY292727 \\
\hline Matthee et al. 2004 & Brachylagus idahoensis & & Unknown & AY292721 \\
\hline
\end{tabular}

the program MEGA to calculate pairwise divergences and nucleotide diversity of ND2 sequences using the maximum composite likelihood model (Tamura et al. 2011). We used the programs DnaSP 5.10.01 (Librado and Rozas 2009) and Network 4.6.10 (Fluxus Technology, Ltd., Suffolk, England 2012) to make a minimum spanning tree of the haplotypes using the median-joining method (Bandelt et al. 1999).

We used the program Phyml (Guindon and Gascuel 2003) for phylogenetic analysis of mammalian cyt $b$ sequences by maximum likelihood methods. We used the default parameters (HKY85 model with gamma-distributed rate variation among sites) and simultaneous estimation of model parameters with 100 bootstrap replicates to assess branch support.

\section{RESUlTs}

The anomalous specimen, MSB: Bird:37574, matched subspecies B. v. saturatus by plumage (Fig. 1). We compared the plumage to New Mexico specimens of B. v. pinorum (63 skins), B. v. pallescens (59 skins), B. v. subarcticus (2 skins), B. v. lagophonus (14 skins), B. v. pallescens $\times$ B. v. virginianus (11 skins), and B. $v$. pallescens $\times$ B. $v$. pinorum (11 skins). The head and dorsum of MSB : Bird:37547 were substantially darker than any of the previously salvaged Great Horned Owl specimens at the MSB. The plumage was also darker than that of any North American Great Horned Owl subspecies other than B. v. saturatus (Fig. 1). The tawny colored feathers on the tarsi and toes also matched B. v. saturatus; all other subspecies known from New Mexico have whitish or buff tarsi and toes (Fig. 1).

Assembled sequences were $864 \mathrm{bp}$ long for owl ND2 and $868 \mathrm{bp}$ for rabbit cyt $b$. The sequence chromatograms were clean and unambiguous, without double peaks or any other evidence of nuclear DNA pseudogenes. Complete sequences are available on Genbank (Table 1).

We sequenced the ND2 gene for a total of 12 Great Horned Owls from 5 different localities and 5 different morphological subspecies (Table 1). We identified 6 unique haplotypes but found no geographic or taxonomic structure in the haplotype network (Fig. 2). As few as 11 nucleotide changes are sufficient to explain all of the observed variation across all 12 Great Horned Owl ND2 sequences $(\sim 0.013$ substitutions per site). MSB : Bird: 37574 was a unique haplotype but differed by 


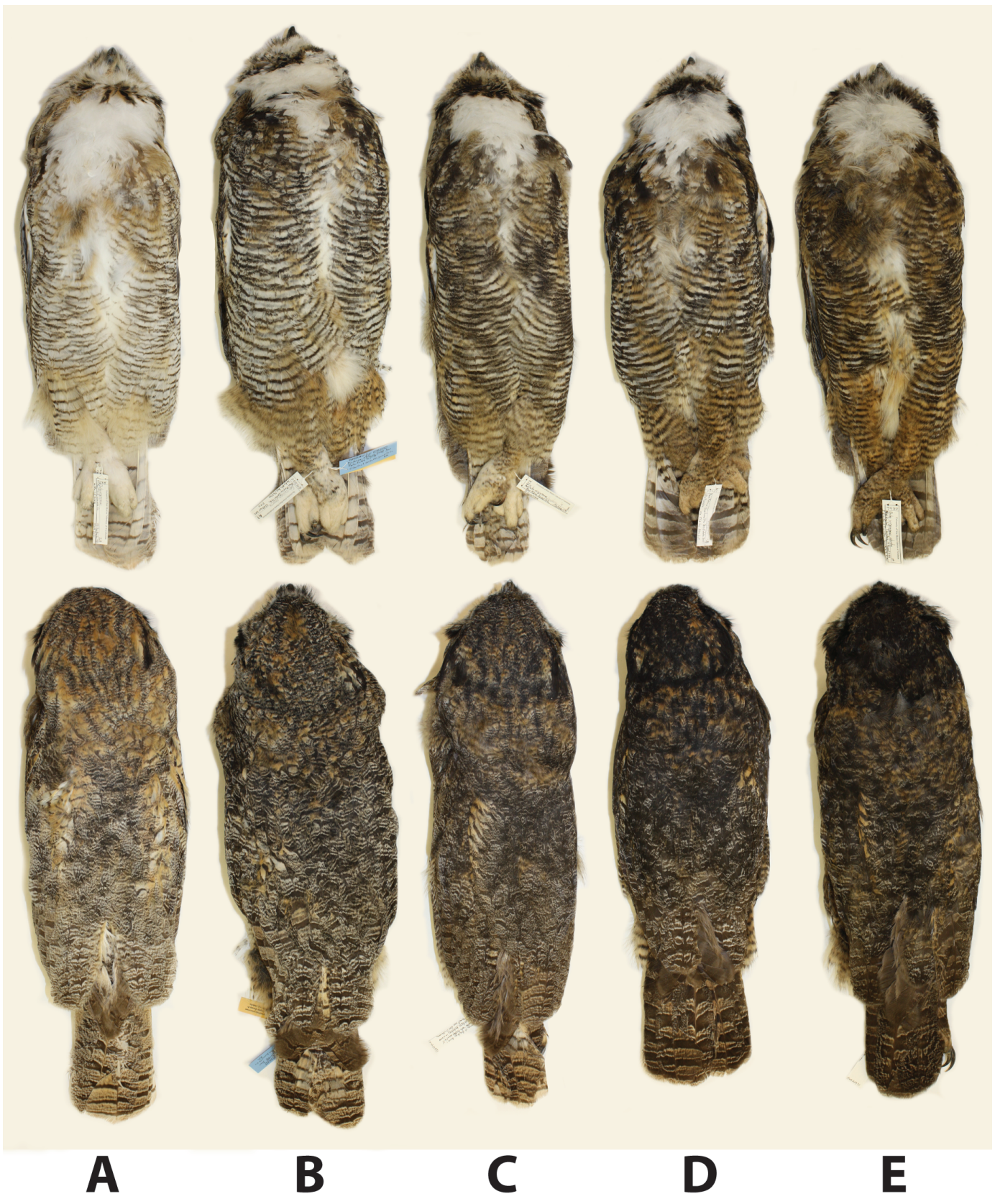

Fig. 1. Ventral and dorsal views of the vagrant owl (D) with exemplars of 4 western North American subspecies: A, Bubo virginianus pallescens (MSB:Bird:9227); B, B. v. pinorum (MSB:Bird:21574); C, B. v. lagophonus (MSB:Bird:19604); D, B. v. saturatus from New Mexico (MSB:Bird:37574); and E, B. v. saturatus from Washington (MSB:Bird:9480).

only one base pair from the most common haplotype (Fig. 2).

We identified the animal found in the stomach of MSB:Mamm:37574 as a juvenile rabbit (Sylvilagus sp.) on the basis of morpho- logical comparisons with MSB specimens. Comparisons of the rabbit's cyt $b$ sequence with previously published sequences indicated that it was a desert cottontail (Sylvilagus audubonii; Table 1, Fig. 3), a species that occurs 

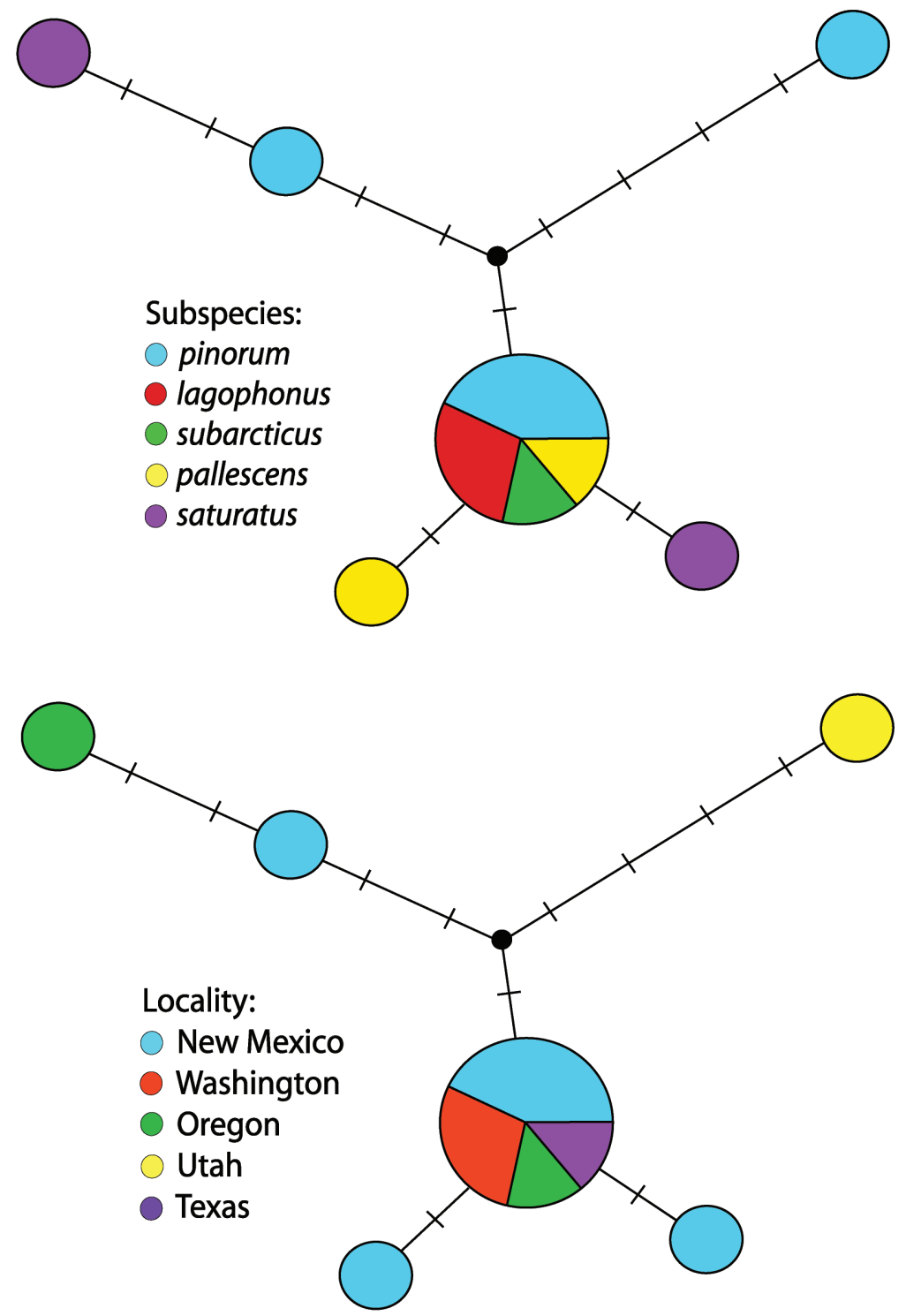

Fig. 2. Minimum spanning network of the 6 ND2 haplotypes detected in the Great Horned Owls, colored by subspecies (top) and locality (bottom). The smaller circles represent haplotypes found in one individual each, whereas the larger circle represents a haplotype found in 7 individuals. The New Mexico Dusky Great Horned Owl specimen is represented by the circle on the bottom right of each network. The black circles represent hypothetical ancestors that were not observed. Each tick mark represents an inferred mutational step.

from central Montana south through the eastern Rocky Mountains and western Great Plains to western and central Texas, New Mexico, Arizona, southern Nevada, southern to north central California, and northwestern and north central Mexico south to Mexico City. The species is largely absent north of $41^{\circ}$ latitude from northern Utah and eastern Idaho west to the Pacific coast (GBIF data), and it is therefore not expected to overlap the breeding distribution of the Dusky Great Horned Owl. The phylogenetic results placed the MSB:Mamm:37574 haplotype with other desert cottontail sequences, nested within a clade of haplotypes from west Texas and central New Mexico. Published sequences of desert 


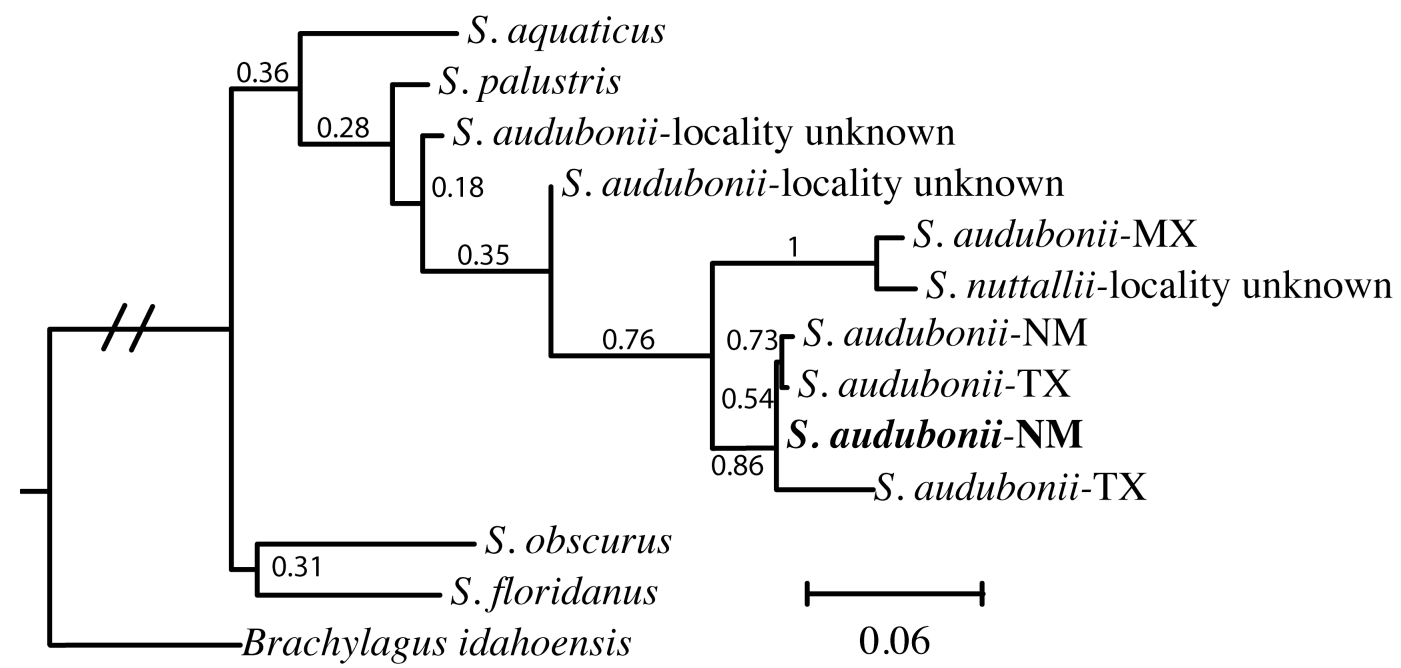

Fig. 3. Phylogeny of Sylvilagus cytochrome $b$ haplotypes. Proportion bootstrap support out of 100 replicates is shown at nodes. The specimen found in the stomach of a Great Horned Owl is shown in bold. Scale bar is in units of substitutions per site.

TABLE 2. Mean between-group levels of percent sequence divergence between Sylvilagus species included in this study.

\begin{tabular}{|c|c|c|c|c|c|}
\hline Species & (1) & (2) & (3) & $(4)$ & (5) \\
\hline $\begin{array}{l}\text { (1) S. audubonii } \\
\text { (2) S. aquaticus }\end{array}$ & 0.091 & & & & \\
\hline (3) S. floridanus & 0.109 & 0.086 & & & \\
\hline (4) S. nuttallii & 0.063 & 0.100 & 0.093 & & \\
\hline (5) S. obscurus & 0.093 & 0.091 & 0.082 & 0.085 & \\
\hline (6) S. palustris & 0.073 & 0.059 & 0.084 & 0.102 & 0.093 \\
\hline
\end{tabular}

cottontail were diverse (mean within-group divergence 5.4\%) and paraphyletic with respect to a published sequence of the mountain cottontail (S. nuttallii; Fig. 3). The specimen from the stomach of the owl was $0.4 \%$ divergent from the other central New Mexico desert cottontail specimen. By contrast, percent divergences among Sylvilagus species were substantially larger $(6.3 \%$ to $10.9 \%$; Table 2$)$.

\section{Discussion}

We conclude that the owl most likely represents subspecies B. v. saturatus, the Dusky Great Horned Owl, and that it arrived in central New Mexico from the coastal Pacific Northwest without having been transported after death. Plumage provides the sole evidence for identification until genetic techniques with higher resolution can be applied to Great Horned Owl phylogeography. We cannot rule out the possibility that this bird may be a melanistic individual from a local population, such as might be produced by a mutation at the MC1-R locus (Mundy et al. 2004). However, a mutant individual would not be expected to closely mimic B. v. saturatus because many possible mutations at different loci can increase melanism by different molecular mechanisms (Hoekstra 2006). Furthermore, there is no evidence of anomalous, melanistic individuals in the series of 411 skins and spread-wing specimens at the MSB.

Our molecular results for Great Horned Owls indicate that levels of mitochondrial diversity are extremely low and that subspecies have not been separated long enough to achieve monophyly. Despite our modest sampling, the current result is a strong preliminary indication that phenotypic divergence among North American Great Horned Owl subspecies occurred during the late Pleistocene, too recently to be accompanied by genetic divergence at loci that are effectively 
neutral. Phylogeographic inference of geographic provenance in North American Great Horned Owls will require the identification of genetic markers that are geographically structured. These may include rapidly evolving markers such as microsatellites (Wink 2006) or loci that are under selection for local adaptation to different environments (e.g., Steiner et al. 2009, Wilson et al. 2013). Emerging next-generation sequencing methods for phylogeography suggest that population-level genome scans for loci under selection will be eminently feasible in the near future (McCormack et al. 2011). Once identified, any geographically structured locus could be used for inferring provenance via widely available and inexpensive Sanger sequencing methods.

The molecular evidence for the rabbit in the owl's stomach suggests that the rabbit had been captured and consumed in central New Mexico where the owl was salvaged. The rabbit's mitochondrial DNA was extremely closely related ( $<0.5 \%$ sequence divergence) to rabbits from west Texas and central New Mexico. Furthermore, the apparent deep genetic structure within the species suggests that desert cottontails from the northern or western parts of the species' distribution would be more divergent. It is clear, however, that a definitive conclusion on the geographic origins of the rabbit must await detailed phylogeographic work on rabbits of the western United States. In this case, unlike the owls, the deep mitochondrial DNA structure indicates that the mitochondrial locus will be sufficient to identify provenance with at least moderate precision, but there are no sequences available for the majority of the species' range. Furthermore, several of the S. audubonii sequences in Genbank currently contain no information about locality or museum specimen vouchers that allows the sequences to be applied to phylogeographic inference (Fig. 3).

Specimen salvage efforts and museum collections of skins and tissues continue to contribute to our understanding of distribution and movements of common North American vertebrate species. Reference databases, in combination with published studies and museum databases, document phylogeographic variation, potentially allowing for genetic identification of the geographic provenance of any sample (e.g., Witt et al. 2010, Baumann et al. 2011, 2013, Engel et al. 2011, Johnson et al.
2011). This study demonstrates 2 scenarios that can limit the phylogeographic inference of provenance. First, recent divergence among Great Horned Owl subspecies has resulted in insufficient genetic variation at an effectively neutral marker locus, mtDNA. Second, reference databases currently contain incomplete phylogeographic coverage for prey species, even for some of the most common and widespread North American vertebrates.

\section{ACKNOWLEDGMENTS}

We thank Shirley S. Kendall for salvaging this specimen (and hundreds of others) for the Museum of Southwestern Biology (MSB). We thank the Global Biodiversity Information Facility (gbif.org) for facilitating access to distribution records of Sylvilagus audubonii from 39 museum collections. We thank ORNIS for facilitating a search for B. v. saturatus specimens from North American bird collections. We thank Andrew B. Johnson, Ernest Valdez, and Jonathan L. Dunnum for help with curation and the identification of stomach contents. We thank Joe Cook and Cheryl Parmenter for access to tissues in the MSB Collection of Genomic Resources. Molecular work was funded in part by NSF-1146491 and the Molecular Biology Facility at the UNM Department of Biology. Two anonymous reviewers improved the manuscript.

\section{Literature Cited}

[AOU] American ORnithologists' Union. 1957. Check-list of North American Birds. 5th edition. American Ornithologists' Union, Washington, DC.

Avise, J.C. 2000. Phylogeography: the history and formation of species. Harvard University Press, Cambridge, MA

Bandelt, H.J., P. Forester, and A. RöHL. 1999. Medianjoining networks for inferring intraspecific phylogenies. Molecular Biology and Evolution 16:37-48.

Baumann, M.J., S.M. McNew, ANd C.C. WitT. 2013. Morphological and molecular evidence confirm the first definitive Eastern White-breasted Nuthatch (Sitta carolinensis) for New Mexico. Western Birds 44:90-97.

Baumann, M.J., N.D. Pederson, J. Oldenettel, M.S. Graus, S.M. MCNew, and C.C. WitT. 2011. Molecular and morphological evidence confirm the first record of Eastern Whip-poor-will (Caprimulgus vociferus) for New Mexico. New Mexico Ornithological Society Bulletin 39:1-10.

EDGAR, R.C. 2004. MUSCLE: a multiple sequence alignment method with reduced time and space complexity. BMC Bioinformatics 5:113.

Dickerman, R.W., AND A.B. Johnson. 2008. Notes on Great Horned Owls nesting in the Rocky Mountains, 
with a description of a new subspecies. Journal of Raptor Research 42:20-28.

Engel, J.I., M.H. Hennan, C.C. Witt, and J.D. WeckSTEIN. 2011. Genetic affinities of three vagrant Cave Swallows (Petrochelidon fulva) from eastern North America. Wilson Journal of Ornithology 123(4): $840-845$.

Grinnell, J., AND A.H. Miller. 1944. The distribution of the birds of California. Pacific Coast Avifauna, No. 27. Cooper Ornithological Club, Berkeley, CA. 608 pp.

Guindon, S., AND O. Gascuel. 2003. A simple, fast and accurate algorithm to estimate large phylogenies by maximum likelihood. Systematic Biology 52 : 696-704.

Halanych, K.M., and T.J. Robinson. 1999. Multiple substitutions affect the phylogenetic utility of cytochrome $b$ and 12s rDNA data: examining a rapid radiation in leporid (Lagomorpha) evolution. Journal of Molecular Evolution 48:369-379.

Hoekstra, H.E. 2006. Genetics, development and evolution of adaptive pigmentation in vertebrates. Heredity $97: 222-234$.

Houston, C.S., D.G. Smith, and C. Rohner. 1998. Great Horned Owl (Bubo virginianus). In: A. Poole, editor, The Birds of North America Online. Cornell Lab of Ornithology, Ithaca, NY. Available from: http://bna .birds.cornell.edu/bna/species/372

Irwin, D.M., T.D. Kocher, AND A.C. Wilson. 1991. Evolution of the cytochrome $b$ gene in mammals. Journal of Molecular Evolution 2:37-55.

Johnson, A.B., S.M. McNew, M.S. Graus, and C.C. WITT. 2011. Mitochondrial DNA and meteorological data suggest a Caribbean origin for New Mexico's first Sooty Tern (Onychoprion fuscatus). Western Birds 42:233-242.

Kimura, M., S.M. Clegg, I.J. Lovette, K.R. Holder, D.J. Girman, B. MilÁ, P. Wade, and T.B. SMith. 2002. Phylogeographical approaches to assessing demographic connectivity between breeding and overwintering regions in a Nearctic-Neotropical warbler (Wilsonia pusilla). Molecular Ecology 11:1605-1616.

Librado, P., AND J. Rozas. 2009. DnaSP v5: a software for comprehensive analysis of DNA polymorphism data. Bioinformatics 25:1451-1452.

Matthee, C.A., B.J. van Vuuren, D. Bell, and T.J. RoBinson. 2004. A molecular supermatrix of the rabbits and hares (Leporidae) allows for the identification of five intercontinental exchanges during the Miocene. Systematic Biology 53:433-447.

McCormack, J.E., S.M. Hird, A.J. Zellmer, B.C. CarSTENS, AND R.T. BRumfield. 2011. Applications of next-generation sequencing to phylogeography and phylogenetics. Molecular Phylogenetics and Evolution 66:526-538.

Mundy, N.I., N.S. Badcock, T. Hart, K. Scribner, K. Janssen, and N.J. Nadeau. 2004. Conserved genetic basis of a quantitative plumage trait involved in mate choice. Science 303:1870-1873.
Nalls, A.V., L.K. Ammerman, and R.C. Dowler. 2012. Genetic and morphologic variation in the Davis Mountains cottontail (Sylvilagus robustus). Southwestern Naturalist 57:1-7.

Ramirez-Silva, J.P., F.X. Gonzalez-Cozatl, E. VasquezDominguez, and F.A. Cervantes. 2010. Phylogenetic position of Mexican jackrabbits within the genus Lepus (Mammalia: Lagomorpha): a molecular perspective. Revista Mexicana de Biodiversidad 81: $721-731$.

RuegG, K.C., AND T.B. Smith. 2002. Not as the crow flies: a historical explanation for circuitous migration in Swainson's Thrush (Catharus ustulatus). Proceedings of the Royal Society of London. Series B: Biological Sciences 269(1498):1375-1381.

Sorenson, M.D., J.C. Ast, D.E. DimchefF, T. Yuri, and D.P. MindelL. 1999. Primers for a PCR-based approach to complete mitochondrial genome sequencing in birds and other vertebrates. Molecular Phylogenetics and Evolution 12:105-114.

Spradling, T.A., M.S. Hafner, and J.W. Demastes. 2001. Difference in rate of cytochrome- $b$ evolution among species of rodents. Journal of Mammology 82:65-80.

Steiner, C.C., H. Rompler, L.M. Boettger, T. SchoneBerg, AND H.E. Hoekstra. 2009. The genetic basis of phenotypic convergence in beach mice: similar pigment patterns but different genes. Molecular Biology and Evolution 26:35-45.

Tamura, K., D. Peterson, N. Peterson, G. Stecher, M. NEI, AND S. Kumar. 2011. MEGA5: molecular evolutionary genetics analysis using maximum likelihood, evolutionary distance, and maximum parsimony methods. Molecular Biology and Evolution 28: 2731-2739.

Webster, M.S., P.P. Marra, S.M. Haig, S. Bensch, and R.T. HoLmes. 2002. Links between worlds: unraveling migratory connectivity. Trends in Ecology and Evolution 17:76-83.

Wilson, R.E., J.L. Peters, and K.G. McCracken. 2013. Genetic and phenotypic divergence between lowand high-altitude populations of two recently diverged Cinnamon Teal subspecies. Evolution 67: $170-184$.

Wink, M. 2006. Use of DNA markers to study bird migration. Journal of Ornithology 147:234-244.

Witt, C.C., M.S. Graus, and H.A. Walker. 2010. Molecular data confirm the first record of the Longbilled Murrelet for New Mexico. Western Birds 41: 160-167.

ZinK, R.M., AND G.F. BARRowClOUgh. 2008. Mitochondrial DNA under siege in avian phylogeography. Molecular Ecology 17:2107-2121.

Received 1 March 2013 Accepted 3 July 2013 